\title{
PENGARUH STRES KERJA, BEBAN KERJA, DAN KONFLIK PEKERJAAN KELUARGA TERHADAP KEPUASAN KERJA KARYAWAN SWISS BELINN HOTEL
}

\author{
I Putu Suartana ${ }^{1}$ \\ I Gusti Ayu Manuati Dewi ${ }^{2}$
}

Fakultas Ekonomi dan Bisnis Universitas Udayana, Bali, Indonesia

email: suartanapt123@gmail.com

\begin{abstract}
ABSTRAK
Tujuan penelitian ini menjelaskan pengaruh stres kerja, beban kerja dan konflik pekerjaankeluarga terhadap kepuasan kerja karyawan. Penelitian ini dilakukan terhadap karyawan di Swiss Belinn Hotel Legian dengan jumlah sampel sebanyak yang ditentukan 60 orang. Pengumpulan data dalam penelitian ini menggunakan kuesioner. Teknik analisis data yang digunakan adalah analisis deskriptif dan analisis inferensial. Hasil penelitian ini menunjukan stres kerja berpengaruh secara negatif dan signifikan terhadap kepuasan kerja, beban kerja berpengaruh secara negatif dan signifikan, dan konflik pekerjaan-keluarga berpengaruh secara negatif dan signifikan terhadap kepuasan kerja karyawan Swiss Belinn Hotel Legian. Pihak manajemen hotel seyogyanya fokus untuk mencari solusi agar kepuasan kerja karyawan meningkat.

Kata Kunci: stres kerja, beban kerja, konflik pekerjaan, kepuasan kerja
\end{abstract}

\begin{abstract}
The purpose of this study explains the effect of work stress, workload and work-family conflict on employee job satisfaction at Swiss Belinn Hotel Legian. This research was conducted at Swiss Belinn Hotel Legian with the research subject of employees involved directly serving consumers with 60 people as respondents. Data collection in this study uses a questionnaire. The analysis technique uses descriptive analysis and inferential analysis. The results of this study show that work stress has a negative and significant effect on job satisfaction of Swiss Belinn Hotel Legian employees, workload negatively and significantly influences the job satisfaction of Swiss Belinn Hotel Legian, work-family conflict has a negative and significant effect on job satisfaction of Swiss employees Belinn Hotel Legian. Reducing employee job satisfaction which results in decreased employee performance. The hotel management should focus on finding solutions to increase employee job satisfaction.

Keywords: work stress, workload, work conflict, job satisfaction
\end{abstract}




\section{PENDAHULUAN}

Globalisasi mengakibatkan adanya tuntutan yang lebih tinggi terhadap tenaga kerja seperti dalam hal penguasaan teknologi baru, waktu kerja yang lebih ketat, peraturan kerja yang lebih ketat dan lain-lain. Kondisi ini dapat menimbulkan tekanan yang lebih berat. Bagi karyawan dalam melaksanakan pekerjaanya yang selanjutnya dapat berdampak pada kepuasan kerja.

Kunci sukses organisasi bisnis salah satunya terletak pada kepuasan kerja karyawannya.Dengan demikian, perusahaan harus berupaya memperbaiki atau meningkatkan kondisi-kondisi yang dapat mempengaruhi kepuasan kerja, sehingga kerugian perusahaan dapat dikurangi dan kinerja dapat ditingkatkan sesuai dengan tujuan yang telah ditetapkan.

Seseorang bekerja dengan tujuan untuk memenuhi kebutuhan hidupnya. Jika kebutuhan terpenuhi, maka karyawan merasa puas, dan sebaliknya, bila kebutuhannya tidak terpenuhi, maka semangat dan gairah kerja turun, merasa bosan bekerja, tingkat kemangkiran meningkat, dan lain sebagainya. Menurut Handoko (2008:183), kepuasan kerja adalah kondisi emosional yang menyenangkan dan tidak menyenangkan dengan mana pegawai memandang pekerjaan mereka. Menurut Hasibuan (2003:202) ,kepuasan kerja adalah sikap emosional yang menyenangkan dan mencintai pekerjaannya. Menurut Ardana (2008:23), kepuasan kerja adalah selisih dari sesuatu yang seharusnya ada dengan yang sesungguhnya. Semakin kecil selisih kondisi yang seharusnya dengan kondisi yang sesungguhnya, seseorang cenderung merasa semakin puas. Berdasarkan beberapa pengertian tersebut, dapat dikatakan bahwa kepuasan kerja merupakan cara pandang seseorang terhadap pekerjaannya.

Kepuasan kerja tergantung pada tingkat perolehan instrinsik dan eksterinsik, dan tergantung dari pandangan pemegang pekerjaan terhadap perolehan tersebut. Unsur kondisi dan perilaku orang terhadap pekerjaannya dianggap sebagai unsurunsur yang dikandung dalam kepuasan kerja. Dewasa ini, kepuasan kerja karyawan sangat mempengaruhi kinerja suatu perusahaan. Kepuasan kerja tentunya harus ditingkatkan karena secara tidak langsung akan berdampak positif terhadap kinerja suatu perusahaan

Biasanya rendahnya stres kerja, beban kerja, dan konflik pekerjaan-keluarga akan dapat meningkatkan kepuasan kerja. Handoko (2008:183) ,menyatakan bahwa stres kerja adalah suatu kondisi ketegangan yang mempengaruhi emosi, proses berpikir, dan kondisi seseorang. Hasilnya, stres kerja yang terlalu tinggi dapat mengancam kemampuan seseorang untuk menghadapi lingkungan, yang akhirnya mengganggu pelaksanaan tugas-tugas dan prestasi kerjanya. Biasanya, stres semakin kuat apabila karyawan menghadapi masalah yang datangnya bertubi-tubi.

Beban kerja menunjukkan rata-rata kegiatan dari suatu pekerjaan dalam jangka waktu tertentu (Irwandy, 2006). Beban kerja dapat dilihat dari secara fisik dan mental. Beban kerja yang ditanggung seorang karyawan terlalu berat, tentu akan menghambat pelaksanaan tugas dan tanggung jawab seorang karyawan. Seorang tenaga kerja tentunya harus mampu memperhatikan beban kerjanya untuk mendapatkan suatu keserasian dalam bekerja, sehingga akan sejalan dengan 
produktivitas yang tinggi, diluar beban tambahan yang datang dari lingkungan bekerja maupun kapasitas dalam bekerja.

Karyawan yang bekerja memiliki keluarga baik orang tua, suami/istri, atau anak-anak. Disatu sisi, seorang karyawan harus mencurahkan perhatian, pikiran, dan tenaga untuk perusahaan tempatnya bekerja. Disisi lain, dia juga harus melakukan hal yang sama terhadap keluarganya. Dari kondisi tersebut akan terbuka peluang konflik karena adanya perbedaan kepentingan berupa kondisi dimana pekerjaan mengganggu kualitas hubungan keluarga atau tuntutan keluarga mengganggu kualitas kerja karyawan (Istijanto, 2010:226) .Kondisi yang disebut dengan konflik pekerjaan-keluarga (KPK) ini dapat menimbulkan berbagai masalah yang mempengaruhi kehidupan keluarga dan pekerjaan seseorang (Soeharto, 2010). Sulitnya menyeimbangkan urusan pekerjaan dan keluarga ini pada akhirnya dapat mempengaruhi kinerja baik laki-laki maupun perempuan yang bekerja (Christines et al. 2010).

Fadhilah (2010) dan Hans et al. (2014) menyatakan bahwa stres kerja berpengaruh negatif terhadap kepuasan kerja karyawan.. Altaf dan Altaf dan Atif (2011) menyatakan bahwa beban kerja berpengaruh negatif terhadap kepuasan kerja. Namun dalam Rehman, et al. (2012), enyatakan ada hubungan positif antara beban kerja dan kepuasan kerja.

Berdasarkan penyebaran kuisioner kepada 10 orang karyawan pada kegiatan survei awal tampak bahwa karyawan mengalami konflik peran ganda., sehingga menyebabkan pelaksanaan pekerjaan menjadi terganggu. Selain itu, masalah dalam keluarga yang dibawa ketempat kerja menggangu kinerja karyawan yang ditandai dengan penurunan konsentrasi kerja. Tabel 1.

\section{Tabel 1.}

Hasil Survei Awal Tentang Konflik Pekerjaan-Keluarga Karyawan di Swiss Belinn Hotel Legian.

\begin{tabular}{|c|c|c|c|c|c|c|}
\hline No. & Pernyataan & $\begin{array}{l}\text { STS } \\
1\end{array}$ & $\begin{array}{c}\text { TS } \\
2\end{array}$ & $\begin{array}{c}\mathbf{K S} \\
3\end{array}$ & $\begin{array}{l}S \\
4\end{array}$ & $\begin{array}{c}\text { SS } \\
5\end{array}$ \\
\hline & $\begin{array}{l}\text { Waktu yang saya curahkan untuk keluarga sangat kurang akibat } \\
\text { pelaksanaan tugas di tempat kerja }\end{array}$ & 1 & 1 & 1 & 4 & 3 \\
\hline 2. & Masalah pekerjaan sering menyita waktu saya untuk keluarga & 1 & - & - & 5 & 4 \\
\hline 3. & $\begin{array}{l}\text { Penggunaan hari libur yang seharusnya untuk keluarga sering } \\
\text { saya gunakan untuk bekerja }\end{array}$ & 1 & 1 & - & 4 & 4 \\
\hline 4. & $\begin{array}{l}\text { Masalah keluarga menyebabkan produktivitas kerja saya } \\
\text { terganggu }\end{array}$ & - & 1 & - & 4 & 5 \\
\hline 5. & Masalah keluarga seringkalimenyita waktu kerja saya & - & - & 2 & 3 & 5 \\
\hline 6. & $\begin{array}{l}\text { Saya sering terlambat tiba di kantor karena harus menyelesaikan } \\
\text { pekerjaan rumah tangga }\end{array}$ & - & - & 1 & 4 & 5 \\
\hline 7. & $\begin{array}{l}\text { Anggota keluarga saya sering mengeluh karena saya terlalu sibuk } \\
\text { bekerja }\end{array}$ & 1 & 1 & 1 & 4 & 3 \\
\hline 8. & Keluarga sering merasa keberatan karena pekerjaan saya & - & 1 & 1 & 5 & 3 \\
\hline 9. & $\begin{array}{l}\text { Kelelahan setelah pulang kerja sering mengganggu hubungan } \\
\text { saya dengan keluarga dirumah }\end{array}$ & 1 & 1 & 1 & 3 & 4 \\
\hline & Total & 5 & 6 & 7 & 36 & 36 \\
\hline
\end{tabular}


Dari hasil survei diawal seperti disajikan pada Tabel 1, dapat dikatakan bahwa terdapat masalah konflik pekerjaan-keluarga yang dialami oleh karyawan Swiss Belinn Hotel Legian. Hal ini dapat dilihat dari banyaknya pernyataan yang berada pada kategori "setuju" dan "sangat setuju" untuk pernyataan (indikator) tentang konflik pekerjaan-keluarga.

Dhamayanti (2006), Pasewark (2006) dan Prawitasari (2007) menyatakan bahwa ada hubungan negatif signifikan antara konflik pekerjaan-keluarga (KPK) dengan kepuasan kerja. Artinya semakin tinggi konflik pekerjaan-keluarga (KPK) maka semakin rendah tingkat kepuasan kerja karyawan, dan sebaliknya, semakin rendah konflik pekerjaan-keluarga (KPK) maka semakin tinggi tingkat kepuasan kerja. Jahanzeb (2010), Soeharto (2010) dan Ru (2011), menyatakan ada hubungan negatif antara konflik pekerjaan-keluarga (KPK) dengan kepuasan kerja. Sikap dan perasaan yang negatif terhadap pekerjaan merupakan akibat dari konflik pekerjaan-keluarga (KPK) yang dialami. Karyawan yang mengalami konflik pekerjaan-keluarga (KPK) cenderung memiliki kepuasan kerja yang lebih rendah.

Teori peran (Role Theory) yang dikembangkan Khan et al. (1964) dalam Lohan (2012) menekankan sifat individual sebagai perilaku yang sesuai dengan posisi yang ditempatinya di lingkungan kerja dan masyarakat. Teori peran menyatakan bahwa individu mengalami konflik apabila ada dua tekanan atau lebih yang yang terjadi secara bersamaan yang ditujukan pada seseorang. Peran ini merupakan elemen dari struktur kelompok yang menjelaskan bagian yang dialami dalam interaksi dengan anggota kelompok yang lain. Peran yang diterima individu sangat ditentukan oleh posisi individu dalam organisasi. Hal tersebut memunculkan sebuah perilaku yang diharapkan dari seseorang yang melakukan peran dalam konteks sosial yang disebut peran yang diharapkan.

Stres kerja berpengaruh negatif terhadap kepuasan kerja karyawan. Hal ini menunjukkan bahwa semakin tinggi stress kerja yang dirasakan oleh karyawan, maka kepuasan kerja karyawan akan menurun atau sebaliknya, semakin rendah stress kerja maka semakin tinggi kepuasan kerja karyawan (Fadhilah, 2010). Karyawan yang tidak puas di pekerjaannya menunjukkan sikap negatif terhadap pekerjaan dan akan merasa stres pada pekerjaan mereka. Stres fisik atau psikologis adalah keadaan tertekan yang dialami oleh individu dalam menghadapi tuntutan yang luar biasa dan kendala dalam pekerjaan mereka (Fadhilah, 2010) Stres kerja memiliki pengaruh negatif yang signifikan terhadap kepuasan kerja, hal ini bermakna stres kerja yang dialami karyawan dapat mempengaruhi apa yang mereka rasakan baik itu menyangkut pekerjaan maupun hasil yang mereka terima (Wibowo, 2014).

Faktor-faktor yang mempengaruhi kepuasan kerja menurut adalah: Kesempatan untuk maju. Dalam hal ini, ada tidaknya kesempatan untuk memperoleh pengalaman dan peningkatan kemampuan selama bekerja. Keamanan kerja.Faktor ini disebut sebagai penunjang kepuasan kerja. Keadaan yang aman mempengaruhi perasaan pegawai selama kerja.Gaji dapat mengakibatkan ketidakpuasan, dan jarang orang mengekspresikan kepuasan kerjanya dengan sejumlah uang yang diperolehnya. Pangkat. Pada pekerjaan yang mendasarkan perbedaan tingkat atau golongan, sehingga pekerjaan tersebut memberikan 
kedudukan tertentu pada orang yang melakukannya. Apabila ada kenaikan gaji, maka sedikit banyaknya akan dianggap sebagai kenaikan pangkat dan kebanggaan terhadap kedudukan yang baru itu akan mengubah perilaku dan perasaan pegawai. Faktor instrinsik dari pekerjaan.Atribut yang ada dalam pekerjaan mensyaratkan keterampilan tertentu. Sukar dan mudahnya serta kebanggaan akan tugas dapat meningkatkan atau menurunkan kepuasan kerja. Kondisi kerja.Termasuk di sini kondisi tempat, ventilasi, penyiaran, kantin dan tempat parkir. Aspek sosial dalam pekerjaan.Aspek sosial dalam pekerjaan merupakan salah satu sikap yang sulit digambarkan tetapi dipandang sebagai faktor yang menunjang puas atau tidaknya pekerja. Fasilitas kesejahteraan. Fasilitas kesejahteraan berupa cuti, dana pensiun, atau perumahan merupakan standar suatu jabatan dan apabila dapat dipenuhi akan menimbulkan rasa puas.

Dimensi terjadinya suatu kepuasan kerja yaitu :Pekerjaan itu sendiri,kepuasan kerja itu sendiri merupakan sumber utama kepuasan, dimana pekerjaan tersebut memberikan tugas yang menarik, kesempatan untuk belajar, kesempatan untuk menerima tanggung jawab dan kemajuan untuk karyawan.Gaji,gaji sebagai faktor multidimensi dalam kepuasan kerja merupakan sejumlah upah/uang yang diterima dan tingkat dimana hal ini bisa dipandang sebagai hal yang dianggap pantas dibandingkan dengan orang lain dalamorganisasi.Kesempatan promosi,kesempatan promosi adalah kesempatan untuk maju dalam organisasi, sepertinya memiliki pengaruh yang berbeda pada kepuasan kerja.Pengawasan (Supervisi), pengawasan merupakan kemampuan penyelia untuk memberikan bantuan teknis dan dukungan perilaku. Rekan kerja, pada umumnya, rekan kerja yang kooperatif merupakan sumber kepuasan kerja yang paling sederhana pada karyawan secara individu.

Indikator stres kerja , dapat dibagi dalam tiga aspek yaitu : Indikator pada psikologis, meliputi :Cepat tersinggung. Tidak komunikatif. Banyak melamun. lelah mental.Indikator pada fisik, meliputi :Meningkatnya detak jantung dan tekanan darah.Lelah secara fisik. Kepala pusing. Masalah tidur (kelebihan atau kekurangan tidur). Indikator pada prilaku, meliputi :Merokok berlebihan. Menunda atau menghindari pekerjaan. Perilaku sabotase. Perilaku makan yang tidak normal (kelebihan atau kekurangan).

Mengklasifikasikan beban kerja kedalam faktor-faktor intrinsik dalam pekerjaan,sebagai berikut : Tuntutan Fisik, kondisi kerja tertentu dapat menghasilkan prestasi kerja yang optimal disamping dampaknya terhadap kinerja pegawai, kondisi fisik berdampak pula terhadap kesehatan mental seorang tenaga kerja. Kondisi fisik pekerja mempunyai pengaruh terhadap kondisi faal dan psikologi seseorang. Dalam hal ini bahwa kondisi kesehatan pegawai harus tetap dalam keadaan sehat saat melakukan pekerjaan, selain istirahat yang cukup juga dengan dukungan sarana tempat kerja yang nyaman dan memadai. Tuntutan tugas, kerja shift kerja malam sering kali menyebabkan kelelahan bagi para pegawai akibat dari beban kerja yang berlebihan.Beban kerja berlebihan dan beban kerja terlalu sedikit dapat berpengaruh terhadap kinerja pegawai. Beban kerja dapat dibedakan menjadi dua katagori yaitu : Beban kerja terlalu banyak/sedikit "Kuantitatif" yang timbul akibat dari tugas tugas yang terlalu banyak/sedikit diberikan kepada tenaga kerja untuk diselesaikan dalam waktu tertentu. Beban 
kerja berlebihan/terlalu sedikit Kualitatif yaitu jika orang merasa tidak mampu untuk melaksanakan suatu tugas atau melaksanakan tugas tidak menggunakan keterampilan dan atau potensi dari tenaga kerja.

Indikator beban kerja meliputi : Target yang harus dicapai,Pandangan individu mengenai besarnya target kerja yang diberikan untuk menyelesaikan pekerjaannya, misalnya untuk membersihkan kamar, menyajikan makanan. Pandangan mengenai hasil kerja yang harus diselesaikan dalam jangka waktu tertentu. Kondisi pekerjaan, mencakup pandangan individu mengenai kondisi pekerjaannya, misalnya terkait pengambil keputusan pada saat pelaksanaan tugas, serta mengatasi kejadian yang tak terduga seperti melakukan pekerjaan ekstra diluar waktu yang telah ditentukan. Standar pekerjaan ,Persepsi individu mengenai pekerjaannya, misalnya perasaan yang timbul mengenai beban kerja yang harus diselesaikan dalam jangka waktu tertentu.

Jahanzeb (2010) bahwa terdapat hubungan negatif dan signifikan antara stres kerja dengan kepuasan kerja. Dinyatakan bahwa semua sumber stres (stressor) memiliki hubungan negatif yang signifikan dengan kepuasan pekerjaan. Tekanan yang brasal dari ketidakselarasan seseorang dengan lingkungannya dapat menimbulkan stres. Stres dialami apabila kebutuhan dan kemampuan seseorang tidak selaras dengan sarana dan tuntutan (Susilawati, 2013). Stres kerja berpengaruh negatif signifikan terhadap variabel kepuasan kerja karyawan pada Hotel Amed Café dan Bungalow yang berarti apabila stres kerja semakin tinggi maka dapat menurunkan kepuasan kerja karyawan (Ariana, 2016).

Stres kerja berhubungan negatif dengan kepuasan kerja karyawan. Organisasi mengerahkan lebih banyak tekanan pada karyawan agar dapat bersaing satu sama lain dan bertentangan dengan tuntutan seperti beban kerja yang berlebihan dan kondisi kerja fisik menyebabkan stres kerja yang menurunkan kepuasan kerja karyawan.

$\mathrm{H}_{1}$ : Stres kerja berpengaruh negatif dan signifikan terhadap kepuasan kerja Karyawan.

Altaf dan Atif (2011). menemukan bahwa beban kerja yang tinggi memiliki pengaruh yang negatif terhadap kepuasan kerja. Mustapha dan Ghee (2013). menyatakan bahwa ada hubungan negatif signifikan antaran beban kerja dan kepuasan kerja. Karyawan lebih puas ketika mereka diberikan beban kerja yang lebih rendah dan kepuasan kerja yang lebih rendah ditemukan pada beban kerja yang lebih tinggi dalam penelitian (Mansoor et al, 2011). Tunggareni dan Nurul (2013). menemukan tenaga keperawatan yang memikili beban kerja objektif sedang cenderung memiliki tingkat kepuasan kerja yang lebih besar dari beban kerja objektif tinggi.

$\mathrm{H}_{2}$ : Beban kerja berpengaruh negatif dan signifikan terhadap kepuasan kerja karyawan.

Konflik pekerjaan-keluarga (KPK) berhubungan negativ dengan kepuasan kerja individu. Tingkat dari konflik pekerjaan-keluarga (KPK) yang lebih besar berhubungan dengan kepuasan kerja yang lebih rendah. Sumber keluarga, yaitu tingkat yang lebih tinggi terhadap cinta keluarga memperkuat hubungan negatif antara konflik pekerjaan-keluarga (KPK) dan kepuasan kerja (Bass et al. 2008). 
Karyawan yang mengalami konflik pekerjaan-keluarga (KPK) yang tinggi cenderung memiliki kepuasan kerja yang lebih rendah.

Soeharto (2010) menyatakan terdapat hubungan negatif antara konflik pekerjaan-keluarga (KPK) dengan kepuasan kerja. Sikap dan perasaan yang negatif terhadap pekerjaan merupakan akibat dari kpk yang dialami. Semua sumber stres memiliki hubungan negatif yang signifikan dengan kepuasan kerja, namun koefisien konflik peran memiliki nilai tertinggi. Hal ini menunjukkan bahwa konflik peran memiliki kontribusi yang besar terhadap ketidakpuasan kerja (Jahanzeb, 2010).Hasil penelitian menunjukkan ketika karyawan merasa tuntutan peran kerja mereka mengganggu pemenuhan peran keluarga maka mempengaruhi sikap mereka terhadap pekerjaan, yang selanjutnya dapat mengakibatkan kepuasan kerja berkurang (Rathi dan Barath, 2013).

Hubungan negatif yang sangat signifikan antara kpk dengan kepuasan kerja berarti semakin tinggi konflik pekerjaan-keluarga (kpk) maka semakin rendah tingkat kepuasan kerja karyawan dan sebaliknya semakin rendah kpk, maka semakin tinggi tingkat kepuasan kerja(Prawitasari et al. 2007). Semakin besar kpk yang terjadi maka akan menurunkan kepuasan kerja karyawan (Dhamayanti, 2006) dan (Anafarta, 2011).

$\mathrm{H}_{3}$ :Konflik pekerjaan-keluarga berpengaruh negatif signifikan terhadap kepuasan kerja karyawan.

\section{METODE PENELITIAN}

Penelitian ini menggunakan pendekatan kuantitatif yang berbentuk asosiatif karena bertujuan untuk mengetahui pengaruh dua variabel bebas atau lebih terhadap satu variabel terikat. Kerangka konseptual penelitian ini dapat dilihat pada Gambar 1.

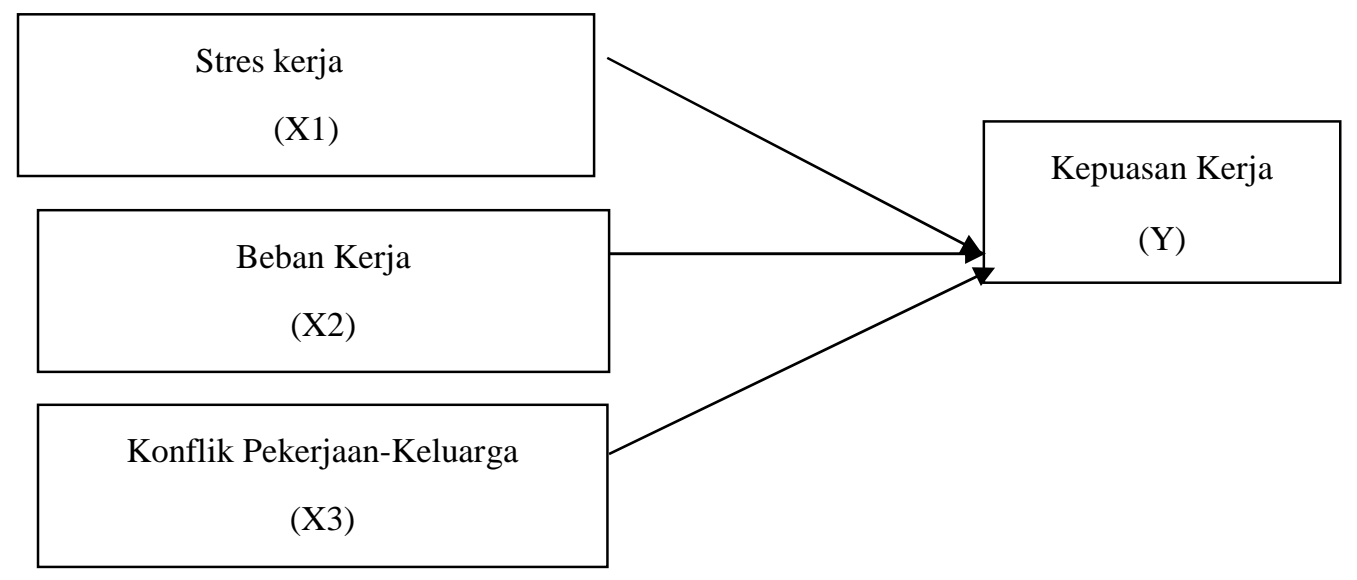

\section{Gambar 1. Kerangka Konseptual}

Lokasi penelitian dilakukan di Hotel Swiss Belinn Legian dengan subjek penelitian karyawan yang terlibat langsung melayani konsumen. Lokasi Hotel Swiss Belinn Legian dipilih karena adanya masalah kepuasan kerja yang dipandang sangat penting dalam mencapai tujuan perusahaan. Obyek dalam 
penelitian ini adalah stres kerja, beban keja, konflik pekerjaan-keluarga, dan kepuasan kerja.

Variabel terikat dalam penelitian ini adalah kepuasan kerja (Y) yang diukur menggunakan lima indikator yaitu pekerjaan itu sendiri, gaji, kesempatan promosi, pengawasan (supervise), dan rekan kerja. Sedangkan variabel bebas dalam penelitian ini adalah stres kerja $\left(\mathrm{X}_{1}\right)$, beban kerja $\left(\mathrm{X}_{2}\right)$, dan konflik pekerjaan-keluarga $\left(\mathrm{X}_{3}\right)$.

Stres kerja $\left(\mathrm{X}_{1}\right)$ diukur menggunakan tiga indikator yaitu psikologis, fisik, dan perilaku. Beban kerja $\left(\mathrm{X}_{2}\right)$ diukur menggunakan tiga indikator yaitu target yang harus dicapai, kondisi pekerjaan, dan standar pekerjaan. Konflik pekerjaankeluarga $\left(\mathrm{X}_{3}\right)$ diukur menggunakan tiga indikator yaitu time-based conflict, strainbased conflict, dan behavior-based conflict. Skala pengukuran yang digunakan dalam penelitian ini menggunakan metode Skala Likert, dari 1 (sangat tidak setuju) sampai 5 (sangat setuju).

Populasi dalam penelitian ini adalah seluruh karyawan di Hotel Swiss Belinn Legian yang berjumlah 60 orang yang semua sudah menikah. Teknik pengambilan sampel dalam penelitian ini adalah sampling jenuh, dimana seluruh anggota populasi dijadikan sampel penelitian. Tabel 2.

Tabel 2.

\begin{tabular}{|c|c|c|}
\hline \multicolumn{3}{|c|}{ Sampel Penelitian Menurut Jabatan Karyawan Swiss Belinn Hotel Legian } \\
\hline No & $\begin{array}{ll}\text { Jabatan } \\
\end{array}$ & Jumlah (Orang) \\
\hline 1 & Food \& Beverage & 25 \\
\hline 2 & Front Office & 4 \\
\hline 3 & Bartender & 3 \\
\hline 4 & Bellboy & 8 \\
\hline 5 & Housekeeping & 14 \\
\hline 6 & Gardener & 6 \\
\hline & Jumlah & 60 \\
\hline
\end{tabular}

Sumber: Swiss Belinn Legian, 2018

Pengumpulan data dalam penelitian ini menggunakan kuesioner yang berupa daftar pernyataan terstruktur yang disebarkan kepada seluruh responden penelitian terkait variabel-variabel penelitian dan variabel demografi. Teknik analisis data yang digunakan dalam penelitian ini adalah analisis regresi linier berganda. Uji asumsi klasik dalam penelitian ini mencakup uji normalitas, multikolinearitas, heteroskedastisitas, dan autokorelasi. Model regresi linier berganda dirumuskan sebagai berikut.

$$
\mathrm{Y}=\mathrm{a}+\mathrm{b}_{1} \mathrm{X}_{1}+\mathrm{b}_{2} \mathrm{X}_{2}+\mathrm{b}_{3} \mathrm{X}_{3}+\mathrm{e}
$$

$$
\begin{aligned}
& \text { Notasi : } \\
& \mathrm{Y}=\text { kepuasan kerja } \\
& \mathrm{a}=\text { konstanta } \\
& \mathrm{X}_{1}=\text { stres kerja } \\
& \mathrm{X}_{2}=\text { beban kerja } \\
& \mathrm{X}_{3}=\text { konflik pekerjaan-keluarga }
\end{aligned}
$$


$\mathrm{b}_{1}=$ koefisien regresi stres kerja

$\mathrm{b}_{2}=$ koefisien regresi beban kerja

$\mathrm{b}_{3}=$ koefisien regresi konflik pekerjaan-keluarga

$\mathrm{e} \quad=$ komponen pengganggu

Uji Validitas, Untuk mengukur validitas kuesioner yang digunakan dalam penelitian ini, dianalisis dengan menggunakan korelasi pearson product moment yang diolah menggunakan software SPSS 20.

Uji Reliabilitas, Instrumen yang reliabel adalah instrumen yang bisa digunakan beberapa kali dan tetap ada kesamaan data dalam waktu yang berbeda. Suatu instrumen dengan Cronbach's Alpha $\geq 0,6$ menunjukan bahwa apabila instrumen nilainya lebih besar dari 0,60 maka instrumen yang digunakan reliabel. Hasil uji reliabelitas menunjukan seluruh instrumen penelitian dikatakan reliabel dimanakeseluruhan instrumen layak digunakan untuk mengumpulkan data. Nilai keseluruhan Cronbach'sAlpha $\geq 0,6$ menunjukan bahwa pengukuran tersebut dapat memeberikan hasil yang konsisten apabila dilakukan pengukuran kembali terhadap subyek yang sama pada waktu yang berbeda.

Sebelum melakukan regresi berganda, terbelih dahulu dilakukan uji asumsi klasik. Model regresi yang baik adalah model regresi yang terbebas dari masalah normalitas, multikolinearitas, dan masalah heterokedasitas. Uji asumsi klasik yang perlu dilakukan terdiri dari :1) Uji Normalitas,Uji normalitas dilakukan untuk menguji apakah dalam residual dari model segresi yang dibuat berdistribusi normal atau tidak Model regresi yang baik adalah yang memiliki distribusi residual yang normal atau mendekati normal. Metode yang digunakan adalah dengan menggunakan Kolmogorov-Smirnov. Data seridual dinyatakan berdistribusi normal apabila Asym Sig (2-tailed) lebih besar dari 0,05.2) Uji Multikolinearitas,Uji multikolinearitas dilakukan untuk menguji apakah terdapat korelasi antara variabel independen. Untuk mengetahui ada tidaknya gejala multikolinearitas dapat dilihat dari nilai tolerance dan variance factor (VIF). Hasil nilai tolerance yang nilainya lebih besar dari 10 persen $(0,10)$ dan VIF yang besarnya kurang dari 10 mengindikasikan tidak adanya gejala multikoliniaritas Uji Heterokedatisitas,3) Uji heterokedatisitas digunakan untuk menguji apakah dalam model regresi terjadi ketidaksamaan varian dari residual suatu pengamatan ke pengamatan lain. Untuk mengetahui adanya gejala heterokedatisitas dilakukan dengan melihat scatterplot. Jika gambar scatterplot tidak menumpuk atau membentuk pola tertenru maka bebas dari hetrokedatisitas Uji Autokorelasi,Uji autokorelasi berkaitan dengan observasi atau data dalam satu variabel yang saling berhubungan satu sama lain.

\section{HASIL DAN PEMBAHASAN}

Uraian Tugas dan Tanggung Jawab General Manager Fungsi, wewenang dan tanggungjawab General Manager adalah sebagai pemimpin utama dalam hotel yang bertugas memberikan arahan serta mengawasi pelaksanaan seluruh kegiatan dilapangan baik menyangkut operasional hotel itu sendiri maupun sistem pelaporan dan hal-hal administratif lainnya sekaligus sebagai pengambil keputusan. GeneralManager bertanggungjawab kepada pihak pemegang saham. 
Executive Secretary,Executive Secretary bertugas membantu General Manager khususnya dalam hal administrasi. Secretary juga bertugas menemani/mendampingi GeneralManager di saat tugas-tugas ekstern yang bertanggungjawab terhadapGeneral Manager. Front Office Manager. Front Office Manager memiliki tugas dan tanggungjawab seperti berikut: Menjual kamar, tugas ini antara lain menerima pemesanan kamar, menangani tamu yang tanpa pemesan kamar, melaksanakan pendaftaran dan penentuan kamar. Memberikan informasi tentang pelayanan hotel. Mengkoordinir pelayanan tamu, antara lain sebagai penghubung antara bagian-bagian di hotel menangani berbagai masalah dan keluhan tamu. Menyusun laporan status kamar dan mengkoordinasikan penjualan kamar dengan bagian house keeping. Menyelenggarakan pembayaran tamu. Menyusun riwayat kunjungan tamu antara lain melakukan pencatatan data-data individu untuk kunjunganakandatangdan menyelenggarakan arsip kartu riwayat kunjungan tamu.Menangani barang-barang bawaan tamu. Executive House Keeper Sesuai dengan namanya, bagian tata graha (house keeper) bertugas menata rumah dalam arti mengatur peralatan, menjaga kebersihan, agarhotel tampak rapi, bersih, menarik dan menyenangkan. Bagian ini mempunyai tugas dan tanggungjawab antara lain mengkoordinir pelaksanaan persiapan kamar yang meliputi perlengkapan, kerapian, kebersihan dan kenyamanan guna memastikan pelayanan maksimal yang diberikan kepada tamu. Selain itu tugasnya juga meliputi binatu atau pencucian dan penyetrikaan, penggantian seprai dikamar, kebersihan area publik dan pengontrolan pemakaian mini bar di kamar oleh tamu.

Food and Beverage Manager Bagian ini bertanggungjawab atas operasional pada visi makanan dan minuman yang meliputi kegiatan di restaurant, room service, konvensi seperti pesta, seminar, ulang tahun, show, dan lain-lain. Juga turut dalam pelaksanaan tugas di dapur yang meliputi main kitchen dan pastry serta ruang makan karyawan atau employee dining room, selain itu tugasnya juga meliputi bagian entertainment seperti bar dan karaoke.menggunakan jasa hotel. Memastikan penjualan kamar memenuhi target, menggiatkan program promosi, baik kamar maupun makanan/minuman dan konvensi lainnya. Juga bertanggungjawab dalam mempertahankan hubungan dengan para pelanggan. Mengatur pelaksanaan proses pemasaran seperti iklan, dan penawaran-penawaran serta menciptakan hubungan-hubungan baru. Mengorganisasi pelaksanaan event tertentu di hotel dan melakukan evaluasi terhadap performa produk yang dimiliki oleh hotel.

Chief Engineering ,Bagian ini bertanggung jawab terhadap pelaksanaan perbaikan dan perawatan perlengkapan yang ada di kamar dan peralatan, mesinmesin, komputer, audio visual, pendingin dan alat elektronik lainnya yang ada di seluruh hotel serta cat hotel yang sering mengalami perubahan sesuai event yang sedang dilaksanakan.

Sales and Marketing: Menyusun perencanaan kerja, Mengumpulkan laporan harian dari tim sales \& marketing, Menyusun rekapitulasi tamu hotel ,Menyusun hotel competitorMemasukkan data laporan ke sistem komputerisasi perhotelan. Mengadakan presentasi laporan sales Menyiapkan sales kit Menyusun laporan mingguan 
Public Relations Officer: Menjalin hubungan baik dengan publik eksternal Menjalin hubungan baik dengan pihak owner dan manajemen.Menyusun agenda promosi di majalah.Menjalin hubungan baik dengan pihak pers. Membuat press release.Menyaring jenis-jenis penawaran untuk promosi yang masuk .Merencanakan dan mengkoordinasikan event-event yang akan diadakan di hotel .Distribusi promosi, misalnya : image, flyers, interactive flyers, Dll .Selalu mengupdate informasi untuk informasi hotel .Pembuatan dan distribusi voucher dan souvenir hotel.

Karakteristik demografi responden dalam penelitian ini diuraikan menurut jenis kelamin, usia, pendidikan, dan masa kerja. Tabel 3.

Tabel 3.

Karakteristik Demografi Responden

\begin{tabular}{llcc}
\hline NO & \multicolumn{1}{c}{ Karakteristik Responden } & Orang & $\begin{array}{c}\text { Jumlah } \\
\text { Persentase (\%) }\end{array}$ \\
\hline 1 & Jenis Kelamin & 41 & 68,3 \\
& Laki-laki & 19 & 31,7 \\
\hline & Perempuan & $\mathbf{6 0}$ & $\mathbf{1 0 0}$ \\
\hline \multirow{2}{*}{ Total } & & \\
& Usia (Tahun) & 13 & 21,7 \\
& $18-22$ & 34 & 56 \\
& $23-27$ & 13 & 21 \\
\hline & $>28$ & $\mathbf{6 0}$ & $\mathbf{1 0 0}$ \\
\hline 3 & Total & & \\
& Pendidikan & 26 & 43 \\
& SMA/SMK & 22 & 36 \\
& Diploma & 12 & 20 \\
\hline Sarjana & $\mathbf{6 0}$ & $\mathbf{1 0 0}$ \\
\hline & Total & & 21 \\
& Masa Kerja & 13 & 50 \\
& $1-5$ tahun & 30 & 28 \\
& 6-10 tahun & 17 & $\mathbf{1 0 0}$ \\
\hline
\end{tabular}

Sumber : Data Primer diolah, 2018

Tabel 3. menunjukkan bahwa jumlah laki-laki sebanyak 41 orang $(68,3 \%)$ dan perempuan sebanyak 19 orang $(31,7 \%)$. Data ini menunjukkan bahwa jumlah karyawan laki-laki adalah 2 kali lipat lebih di bandingkan dengan jumlah karyawan perempuan. Kondisi ini disebabkan pekerjaan di hotel ini lebih banyak membutuhkan karyawan laki-laki dibandingkan perempuan. Responden yang berusia antara 18-22 tahun adalah sebanyak 13 orang (21,67 persen). Responden yang berusia antara 23-27 tahun adalah sebanyak 34orang $(56,66 \%)$ dan usia $>28$ tahun sebanyak 13 orang $(21,67 \%)$.Hal ini menunjukkan Swiss Belinn Hotel Legian lebih dominan usia 23-27 Tahun. 
Menurut pendidikan tingkat pendidikan SMA/SMK sebanyak 26 orang (43,33\%), tingkat pendidikan diploma sebanyak 22 orang $(36,67 \%)$ dan tingkat pendidikan sarjana sebanyak 12 orang (20\%). Kondisi ini mengindikasikan bahwa karyawan hotel ini dominasi lulusan sekolah lanjutan tingkat atas. Berdasarkan masa kerja menunjukkan bahwa responden dengan masa kerja 1- 5 tahun sebanyak 13 orang $(21,67 \%)$, masa kerja $6-10$ tahun sebanyak 30 orang $(50 \%)$ dan masa kerja > 10 tahun sebanyak 17 orang $(28,33 \%)$, hal ini menggambarkan bahwa rata-rata masa kerja karyawan adalah lebih dari enam tahun.

Suatu instrumen yang valid ditunjukkan dengan $\mathrm{r}$ Pearson Correlation $\geq$ 0,30. Hasil uji validitas pada Tabel 4. menunjukkan bahwa seluruh pernyataan pada variabel stres kerja, beban kerja, konflik pekerjaan-keluarga (kpk), dan kepuasan kerja memiliki nilai koefisien pearson product moment correlation dengan skor total seluruh pernyataan lebih besar dari 0,30 , sehingga seluruh indikator tersebut telah memenuhi syarat validitas data.

Uji reliabilitas dilakukan untuk menunjukkan sejauh mana suatu pengukuran kembali terhadap gejala yang sama. Suatu instrumen dikatakan reliabel apabila instrumen tersebut telah beberapa kali digunakan untuk mengukur objek yang sama dan menghasilkan data atau jawaban yang sama dari waktu ke waktu. Pengujian reliabilitas tiap butir pertanyaan atau pernyataan dalam instrumen penelitian ini menggunakan metode koefisien Cronbach's Alpha. Instrumen dikatakan reliabel untuk mengukur variabel bila berada di atas nilai 0,60. Hasil uji reliabilitas dapat dilihat pada Tabel 4.

Tabel 4.

Hasil Uji Validitas Instrumen Penelitian

\begin{tabular}{|c|c|c|c|c|}
\hline No & Variabel & $\begin{array}{c}\text { Butir } \\
\text { Pernyataan }\end{array}$ & Korelasi Total & Keterangan \\
\hline \multirow{12}{*}{1} & \multirow{12}{*}{ Stres kerja $\left(\mathrm{X}_{1}\right)$} & $\mathrm{X}_{1.1}$ & 0,810 & Valid \\
\hline & & $\mathrm{X}_{1.2}$ & 0,675 & Valid \\
\hline & & $\mathrm{X}_{1.3}$ & 0,854 & Valid \\
\hline & & $\mathrm{X}_{1.4}$ & 0,855 & Valid \\
\hline & & $\mathrm{X}_{1.5}$ & 0,793 & Valid \\
\hline & & $\mathrm{X}_{1.6}$ & 0,811 & Valid \\
\hline & & $\mathrm{X}_{1.7}$ & 0,802 & Valid \\
\hline & & $\mathrm{X}_{1.8}$ & 0,744 & Valid \\
\hline & & $\mathrm{X}_{1.9}$ & 0,811 & Valid \\
\hline & & $\mathrm{X}_{1.10}$ & 0,837 & Valid \\
\hline & & $\mathrm{X}_{1.11}$ & 0,855 & Valid \\
\hline & & $\mathrm{X}_{1.12}$ & 0,780 & Valid \\
\hline \multirow{8}{*}{2} & \multirow{8}{*}{ Beban kerja $\left(\mathrm{X}_{2}\right)$} & $\mathrm{X}_{2.1}$ & 0,844 & Valid \\
\hline & & $\mathrm{X}_{2.2}$ & 0,813 & Valid \\
\hline & & $\mathrm{X}_{2.3}$ & 0,861 & Valid \\
\hline & & $\mathrm{X}_{2.4}$ & 0,802 & Valid \\
\hline & & $\mathrm{X}_{2.5}$ & 0,661 & Valid \\
\hline & & $\mathrm{X}_{2.6}$ & 0,852 & Valid \\
\hline & & $\mathrm{X}_{2.7}$ & 0,741 & Valid \\
\hline & & $\mathrm{X}_{2.8}$ & 0,807 & Valid \\
\hline
\end{tabular}

Bersambung... 
Lanjutan Tabel 4.

\begin{tabular}{llccc}
\hline No & Variabel & $\begin{array}{c}\text { Butir } \\
\text { Pernyataan }\end{array}$ & Korelasi Total & Keterangan \\
\hline \multirow{6}{*}{3} & $\mathrm{X}_{3.1}$ & 0,895 & Valid \\
& & $\mathrm{X}_{3.2}$ & 0,832 & Valid \\
& & $\mathrm{X}_{3.3}$ & 0,811 & Valid \\
& Konflik pekerjaan-keluarga & $\mathrm{X}_{3.4}$ & 0,779 & Valid \\
& $\left(\mathrm{X}_{3}\right)$ & $\mathrm{X}_{3.5}$ & 0,713 & Valid \\
& & $\mathrm{X}_{3.6}$ & 0,803 & Valid \\
& & $\mathrm{X}_{3.7}$ & 0,751 & Valid \\
& & $\mathrm{X}_{3.8}$ & 0,368 & Valid \\
& & $\mathrm{X}_{3.9}$ & 0,345 & Valid \\
\hline \multirow{4}{*}{4} & $\mathrm{Y}_{1.1}$ & 0,810 & Valid \\
& & $\mathrm{Y}_{1.2}$ & 0,674 & Valid \\
& & $\mathrm{Y}_{1.3}$ & 0,877 & Valid \\
& & $\mathrm{Y}_{1.4}$ & 0,787 & Valid \\
& & $\mathrm{Y}_{1.5}$ & 0,831 & Valid \\
\hline
\end{tabular}

Sumber : Data Primer diolah, 2018

Berdasarkan Tabel 5. dapat dilihat bahwa ketiga variabel penelitian yaitu stres kerja, beban kerja, konflik pekerjaan-keluarga dan kepuasan kerja karyawan memiliki koefisien Cronbach's Alpha lebih besar dari 0,60 sehingga seluruh pernyataan tersebut memenuhi syarat reliabilitas instrumen.

Tabel 5.

Hasil Uji Reliabilitas Instrumen Penelitian

\begin{tabular}{clcc}
\hline No & \multicolumn{1}{c}{ Variabel } & Cronbad's Alpha & Keterangan \\
\hline 1 & Stres kerja $\left(\mathrm{X}_{1}\right)$ & 0,949 & Reliabel \\
2 & Beban kerja $\left(\mathrm{X}_{2}\right)$ & 0,918 & Reliabel \\
3 & Konflik pekerjaan-keluarga $\left(\mathrm{X}_{3}\right)$ & 0,870 & Reliabel \\
4 & Kepuasan kerja $(\mathrm{Y})$ & 0,852 & Reliabel \\
\hline
\end{tabular}

Sumber : Data Primer diolah, 2018

Uji normalitas menggunakan uji Kolmogorov-Smirnov, dengan uji ini dapat diketahui data yang digunakan berdistribusi normal atau tidak. Apabila Sign t hitung $>0.05$, maka data tersebut berdistribusi normal dan begitu juga sebaliknya (Santoso, 2001). Berdasarkan Tabel 6. dapat diketahui bahwa nilai Asymp. Sig. (2tailed) sebesar 0,200 dan lebih besar dari $\alpha=0,05$. Jadi, dapat disimpulkan bahwa data tersebut telah memenuhi syarat normalitas dan data dikatakan berdistribusi normal.

Uji multikolinieritas digunakan untuk mengetahui apakah antara variabel bebas terjadi multikolinieritas atau tidak. Uji yang digunakan yaitu dengan melihat nilai VIF (Varian Inflation Factor) dan Tolerance pada proses regresi biasa, jika keduanya mendekati 1 atau besaran VIF kurang dari 10 maka model tidak terkena multikolinieritas. Berdasarkan hasil pengujian multikolinearitas dapat diperoleh hasil seperti terlihat pada Tabel 7. 
Tabel 6.

Hasil Uji Normalitas

\begin{tabular}{llc}
\hline & & Unstandardized Residual \\
\hline $\mathrm{N}$ & & 60 \\
Normal Parameters & Mean & .0000000 \\
& Std. Deviation & 2.56872741 \\
Most Extreme Differences & Absolute & .079 \\
& Positive & .079 \\
& Negative & -.041 \\
Test Statistic & & .079 \\
Asymp. Sig. (2-tailed) & & $.200^{\text {c,d }}$ \\
\hline Sumber : Data Primer diolah, 2018 &
\end{tabular}

Tabel 7.

Hasil Uji Multikolinearitas

\begin{tabular}{lcc}
\hline & \multicolumn{2}{c}{ Collinearity Statistics } \\
Variabel & Tolerance & VIF \\
\hline Stres kerja & 0,543 & 1,842 \\
Beban kerja & 0,587 & 1,703 \\
Konflik pekerjaan keluarga & 0,558 & 1,793 \\
\hline
\end{tabular}

Sumber : Data Primer diolah, 2018

Hasil pengujian tolerance menunjukan seluruh variabel bebas memiliki nilai tolerance lebih besar dari 0,10 (10\%). Hasil perhitungan VIF juga menunjukan bahwa seluruh variabel bebas memiliki nilai VIF kurang dari 10.Oleh karena itu, maka dapat disimpulkan bahwa tidak terjadi multikolinearitas antar variabel bebas dalam model regresi tersebut.

Uji Heterokedastisitas dilakukan untuk menguji apakah dalam model regresi terjadi ketidaksamaan varian dari residu satu pengamatan ke pengamatan lain. Model regresi yang baik adalah model homokedastisitas atau tidak terjadi heterokedastisitas. Apabila model suatu regresi mengandung gejala heterokedastisitas, maka hasil yang diberikan akan menyimpang. Untuk mengetahui apakah sebuah regresi memiliki indikasi heterokedastisitas, maka masalah tersebut bisa dideteksi dengan menggunakan uji Glejser Test. Jika probabilitas signifikansinya di atas 0,05 maka dapat dikatakan bahwa pada model regresi tidak mengandung masalah heterokedastisitas. Hasil pengujian menunjukkan bahwa signifikansinya lebih dari $\alpha=0,05$ terhadap absolut residual secara parsial. Berdasarkan hal tersebut, maka dapat disimpulkan bahwa dalam model regresi tersebut tidak terdapat heteroskedastisitas. Hasil uji heterokedastisitas dapat dilihat pada Tabel 8.

Tabel 8.

Hasil Uji Heteroskedastisitas

\begin{tabular}{lcc}
\hline Variabel & T & Signifikansi \\
\hline Stres kerja & 0,694 & 0,490 \\
Beban kerja & $-1,254$ & 0,215 \\
Konflik pekerjaan keluarga & $-0,736$ & 0,465 \\
\hline
\end{tabular}

Sumber : Data Primer diolah, 2018 
Model analisis regresi linier berganda digunakan untuk menguji hipotesis yang digunakan. Adapun hasil analisis regresi linier berganda yang dilakukan dengan program Statitical Pacage of Social Science (SPSS) versi 21.0 for Windows dapat dilihat pada Tabel 9.

Tabel 9.

Hasil Analisis Regresi Linear Berganda

\begin{tabular}{llcccc}
\hline \multirow{2}{*}{ Variabel } & & \multicolumn{2}{c}{ Koefisien Regresi } & \multirow{2}{*}{ t } & \multirow{2}{*}{ Sig } \\
\cline { 3 - 4 } & & B & Std. error & & \\
\hline Stres kerja & & $-0,164$ & 0,058 & $-2,808$ & 0,007 \\
Beban kerja & $-0,183$ & 0,062 & $-2,941$ & 0,005 \\
Konflik pekerjaan-keluarga & $-0,182$ & 0,063 & $-2,906$ & 0,005 \\
(Constant) : 28,105 & & & & & \\
\hline F Statistik & $:$ & 32,204 & & & \\
Sig F & $: 0,000$ & $:$ & & & \\
$\mathrm{R}^{2}$ & $: 0,633$ & & & \\
\hline
\end{tabular}

Sumber : Data Primer diolah, 2018

Berdasarkan Tabel 9. dapat ditulis persamaan regresi linear berganda sebagai berikut.

$$
\begin{aligned}
& \mathrm{Y}=28,105-0,164 \mathrm{X}_{1}-0,183 \mathrm{X}_{2}-0,182 \mathrm{X}_{3} \\
& \text { Dimana } \\
& \mathrm{Y}=\text { kepuasan kerja } \\
& \mathrm{X}_{1}=\text { stres kerja } \\
& \mathrm{X}_{2}=\text { beban kerja } \\
& \mathrm{X}_{3}=\text { konflik pekerjaan keluarga }
\end{aligned}
$$

Persamaan regresi linear berganda tersebut menunjukkan arah masingmasing variabel bebas terhadap variabel terikatnya. Persamaan regresi liniar berganda tersebut dapat diuraikan yaitu $\mathrm{X}_{1}=-0,164$, menunjukkan bahwa stres kerja berpengaruh negatif terhadap kepuasan kerja karyawan pada Hotel Swiss Belinn Legian. Dengan kata lain apabila stres kerja semakin meningkat, maka kepuasan kerja karyawan Hotel Swiss Belinn Legianakan mengalami penurunan. $\mathrm{X}_{2}=-0,183$, menunjukkan bahwa beban kerja berpengaruh negatif terhadap kepuasan kerja karyawan pada Hotel Swiss Belinn Legian. Dengan kata lain, apabila beban kerja mengalami peningkatan maka kepuasan kerja karyawan Swiss Belinn Hotel Legian akan mengalami penurunan. $X_{3}=-0,182$, menunjukkan bahwa konflik pekerjaan-keluarga berpengaruh negatif terhadap kepuasan kerja karyawan pada Swiss Belinn Hotel Legian. Kondisi ini berarti bahwa apabila konflik pekerjaan-keluarga mengalami peningkatan maka kepuasan kerja karyawan Swiss Belinn Hotel Legian akan mengalami penurunan.

Berdasarkan Tabel 9. menunjukkan bahwa koefisien determinasi yaitu nilai adjusted $R^{2}$ adalah 0,633 yang berarti bahwa sebesar 63,3 persen kepuasan kerja karyawan Swiss Belinn Hotel Legian dipengaruhi oleh stres kerja, beban kerja dan konflik pekerjaan keluarga, sedangkan sisanya sebesar 36,7 persen dipengaruhi oleh variabel lain di luar model penelitian.

Hasil Uji Anova atau ( $F$ test) menunjukkan nilai F hitung sebesar 32,204, dengan signifikansi 0,000 yang probabilitas signifikansi lebih kecil dari alpha 
0,05. Ini menunjukkan bahwa stres kerja, beban kerja dan konflik pekerjaankeluarga dapat digunakan untuk memprediksi kepuasan kerja karyawan Swiss Belinn Hotel Legian atau dapat dikatakan bahwa stres kerja, beban kerja dan konflik pekerjaan keluarga secara bersama-sama berpengaruh terhadap kepuasan kerja karyawan Hotel Swiss Belinn Legian. Dengan demikian, model yang digunakan pada penelitian ini adalah layak untuk uji $t$ statistik yang menguji variabel independen secara parsial terhadap variabel dependen.

Uji parsial (uji t) digunakan untuk menguji pengaruh masing-masing variabel bebas (stres kerja, beban kerja, dan konflik pekerjaan keluarga) terhadap variabel terikat (kepuasan kerja). Apabila nilai signifikansinya $>0,05$ maka hipotesis ditolak (koefisien regresi tidak signifikan), dan apabila nilai signifikansi $\leq 0,05$ maka hipotesis diterima (koefisien regresi signifikan).

Berdasarkan hasil analisis diperoleh nilai sig $=0,007<0,05$ maka $\mathrm{H}_{0}$ ditolak artinya ada pengaruh variabel stres kerja terhadap variabel kepuasan kerja Swiss Belinn Hotel Legian. Ini berarti bahwa stres kerja berpengaruh signifikan terhadap kepuasan kerja Swiss Belinn Hotel Legian.

Pengujian hipotesis pada pengaruh stres kerja terhadap kepuasan kerja Swiss Belinn Hotel Legian menunjukkan bahwa hipotesis pertama ini terdulu nya. Stres kerja berpengaruh negatif signifikan terhadap kepuasan kerja karyawan Swiss Belinn Hotel Legian. Hasil penelitian ini mendukung hasil penelitian terdahulu yang dilakukan oleh Jahanzeb (2010). stres kerja berpengaruh negatif dan signifikan terhadap kepuasan kerja. Berarti jika karyawan mengalami stres dalam pekerjaannya maka terdapat kecenderungan kepuasan kerja mereka akan menurun, tekanan yang berasal dari ketidakselarasan seseorang dengan lingkungannya dapat menimbulkan stres. Stres dialami apabila kebutuhan dan kemampuan seseorang tidak selaras dengan sarana dantuntutan, (Hans et al, 2014). Stres fisik atau psikologis adalah keadaan tertekan yang dialami oleh individu menghadapi tuntutan yang luar biasa dan kendala dalam pekerjaan mereka(Hans et al, 2014). Stres kerja yang dialami oleh karyawan dapat mempengaruhi apa yang mereka rasakan baik itu menyangkut pekerjaan maupun hasil yang mereka terima (Wibowo, 2014). Kepuasan kerja yang lebih rendah akan mengalami lebih banyak stress dalam bentuk beban kerja, konflik peran dan lingkungan fisik dibandingkan dengan kepuasan kerja yang lebih tinggi, Mansoor et al. 2011).

Berdasarkan hasil analisis diperoleh nilai sig $=0,005<0,05$ maka $\mathrm{H}_{0}$ ditolak artinya ada pengaruh variabel beban kerja terhadap kepuasan kerja karyawan Swiss Belinn Hotel Legian. Ini berarti bahwa variabel beban kerja berpengaruh signifikan terhadap kepuasan kerja karyawan Swiss Belinn Hotel Legian.

Pengujian hipotesis pada pengaruh beban kerja terhadap kepuasan kerja karyawan Swiss Belinn Hotel Legian menunjukkan bahwa hipotesis kedua ini terdahulunya. Beban kerja berpengaruh negatif signifikan terhadap kepuasan kerja Altaf \& Atif (2011). Jika karyawan mengalami beban kerja dalam pekerjaannya maka dapat kecenderungan kepuasan kerja mereka akan menurun, (Mansoor et al. 2011). Hal tersebut berarti bahwa semakin tinggi tingkat beban kerja maka akan semakin tinggi tingkat kepuasan kerja karyawan Swiss Belinn Hotel Legian. Hasil ini sejalan dengan penelitian terdahulu beban kerja, secara langsung 
mempengaruhi kecenderungan konsumsi hedonis, emosi positif, kepuasan kerja (Pattipelohi et al. 2013)

Berdasarkan hasil analisis diperoleh nilaisig $=0,005<0,05$ maka $\mathrm{H}_{0}$ ditolak artinya ada pengaruh variabel konflik pekerjaan-keluarga terhadap kepuasan kerja Swiss Belinn Hotel Legian. Ini berarti bahwa variabel konflik pekerjaan-keluarga berpengaruh signifikan terhadap kepuasan kerja Swiss Belinn Hotel Legian.

Pengujian hipotesis pada pengaruh konflik pekerjaan-keluarga terhadap kepuasan kerja karyawan Swiss Belinn Hotel Legian menunjukkan bahwa hipotesis ketiga ini terdulunya. Konflik pekerjaan-keluarga (KPK) berpengaruh negatif signifikan terhadap kepuasan kerja karyawan Swiss Belinn Hotel Legian, hal tersebut berarti bahwa semakin tinggi tingkat konflik pekerjaan-keluarga maka akan semakin rendah tingkat kepuasan kerja karyawan Swiss Belinn Hotel Legian. Hasil ini sejalan dengan penelitian terdahulu yang dilakukan oleh Prawitasari (2007). Hubungan negatif yang sangat signifikan antara KPK dengan kepuasan kerja, yang artinya semakin tinggi KPK maka semakin rendah tingkat kepuasan kerja karyawan dan sebaliknya semakin rendah KPK maka semakin tinggi tingkat kepuasan kerja. Terdapat pengaruh yang negatif dan signifikan antara KPK terhadap kepuasan kerja karyawan. Semakin besar KPK yang terjadi maka akan menurunkan kepuasan kerja karyawan .(Rathi \& Barath, (2013) hasil penelitian menunjukkan ketika karyawan merasa bahwa tuntutan peran kerja mereka mengganggu pemenuhan peran keluarga maka mempengaruhi sikap mereka terhadap pekerjaan, yang selanjutnya dapat mengakibatkan kepuasan kerja berkurang.

\section{SIMPULAN}

Berdasarkan pembahasan hasil penelitian dapat disimpulkan bahwa Stres kerja berpengaruh secara negatif dan signifikan terhadap kepuasan kerja karyawan Swiss Belinn Hotel Legian. Hal tersebut berarti semakin tinggi stres kerja,maka akan menurunkan kepuasan kerja karyawan Swiss Belinn Hotel Legian. Beban kerja berpengaruh secara negatif dan signifikan terhadap kepuasan kerja Swiss Belinn Hotel Legian. Hal tersebut berarti beban kerja yang tinggi, maka akan menurunkan kepuasan kerja karyawan Swiss Belinn Hotel Legian. Konflik pekerjaan-keluarga berpengaruh secara negatif dan signifikan terhadap kepuasan kerja karyawan Swiss Belinn Hotel Legian. Hal tersebut berarti KPK yang tinggi, maka akan menurunkan kepuasan kerja karyawan Swiss Belinn Hotel Legian.

Saran yang dapat diberikan adalah manajemen Swiss Belinn Hotel Legian mengadakan family gatering kepada karyawan setiap 6 bulan untuk menciptakan keakraban dan komunikasi sesama karyawan serta diberlakukannya kerja tim yang bergilir agar sesama karyawan lebih saling mengenal. Selain itu sebaiknya manajemen hotel tidak memberikan beban pekerjaan lebih kepada karyawan agar karyawan tersebut tidak mengambil pekerjaan di saat jam istirahat. Perusahaan dapat mempertahankan sistem promosi yang ada di Swiss Belinn Hotel Legian. Kepuasan kerja dapat tercapai karena karyawan mencintai pekerjaannya. Bagi akademisi, dalam penelitian dimasa mendatang perlu dipertimbangkan untuk menggunakan variabel lain serta memperluas cakupan wilayah penelitian 
misalnya dengan mengambil responden yang tidak hanya Hotel Swiss Belinn

Legian saja, melainkan dapat menambah responden hotel lain.

\section{REFERENSI}

Alamsyah, M. I. (2015). Pengaruh Motivasi Dan Beban Kerja Terhadap Kepuasan Kerja Karyawan Pada Dinas Perindustrian, Perdagangan, Koperasi Dan Usaha Kecil Menengah Daerah Istimewa Yogyakarta. Skripsi Fakultas Ekonomi Universitas Negeri Yogyakarta.

Altaf, A., \& Awan, M. A. (2011). Moderating Affect of workplace sprituality on the relationship of job overload and job satisfaction. Jurnal of business ethics, 104

Anafarta, N. (2011). The Relationship between Work-Family Conflict and Job Satisfaction: A Structural Equation Modeling (SEM) Approach. International Journal of Business and Management, 6 (4)

Ardana, K., Mujiati, N. W. dan Sriathi, A. A. A.. 2008. Perilaku Keorganisaian. Edisi Pertama. Graha Ilmu Yogyakarta.

Ariana, I W. J. dan Riana, I G. (2016). Pengaruh Work-Family Conflict, Keterlibatan Kerja Dan Stres Kerja Terhadap Kepuasan Kerja Karyawan. EJurnal Manajemen Unud, 5(7), 2016: 4630 - 4659

Bass, Brenda L., Butler., Adam B., Grzywacz., Joseph G., Linney., Kirsten D. (2008). Work-Family Conflict And Job Satisfaction: Family Resources As A Buffer. Journal Of Family And Consumer Sciences, 100 (1), Pp: 24

Beehr, T. A.Newman J. E. (1978). Job Sress. Employee health, and Organization Effectiveness. A facet analysis, Model and literatur review, Personnel Psychology.

Christine W.S., Megawati Oktorina., Indah Mula. (2010). Pengaruh Konflik Pekerjaan Dan Konflik Keluarga Terhadap Kinerja Dengan Konflik Pekerjaan-keluarga Sebagai Intervening Variabel (Studi Pada Dual Career Couple Di Jabodetabek). Jurnal Manajemen Dan Kewirausahaan, 12 (2), $121-132$

Daft, L. (2003). Manajemen. Edisi Kelima. Jakarta: Erlangga.

Dhamayanti. (2006). Pengaruh Konflik Keluarga-Pekerjaan, Keterlibatan Pekerjaan, Dan Tekanan Pekerjaan Terhadap Kepuasan Kerja Karyawan Wanita Studi Pada Nusantara Tour \& Travel Kantor Cabang Dan Kantor Pusat Semarang. Jurnal Studi Manajemen \& Organisasi, 3 (2), 93 - 105

Fadhilah, M. L. (2010). Analisis Pengaruh Stress Kerja Terhadap Kepuasan Kerja Dengan Dukungan Sosial Sebagai Variabel Moderating (Studi Pada Pt. Coca Cola Amatil Indonesia, Central Java). Thesis Tidak Diterbitkan. Semarang:Fakultas Ekonomi Universitas Diponegoro. 
Gani, I. \& Amelia, S. (2015). Alat Analisis Data; Aplikasi Statistic untuk Penelitian Bidang Ekonomi dan Sosial. Yogyakarta: percetakan CV. Andi Offset.

Ghozali, Imam. (2011). Aplikasi Analisis Multivariate dengan Program IBM SPSS 19. Semarang: Badan Penerbit Universitas Diponegoro.

Griffin, R W. dan Gregory Moorhead. (2014). Organizational Behavior: Managing People and Organizations. Eleventh Edition, United States of America: South-Western.

Handoko, T.H, (2008). Manajemen personalia sumber Daya Manusia, Edisi Kedua, Yogyakarta, Penerbit : BPFE.

Hans, Arvind., Soofi Asra Mubeen., Sultan Khan., \& Saadi, A. S. M. A. (2014). A Study on Work Stress and Job Satisfaction among Headmasters: A Case Study of Bilingual Schools in Sultanate of Oman - Muscat. Journal Of Sociological Research, 5 (1).

Hasibuan, M.S.P, (2003). Manajemen Sumber Daya Manusia, Stie Ykpn, Yogyakarta.

Hsu, Yu Ru. (2011). Work-Family Conflict And Job Satisfaction In Stressful Working Environments The Moderating Roles Of Perceived Supervisor Support And Internal Locus Of Control. International Journal Of Manpower, 32(2), Pp 233248.

Istijanto. (2010). Riset Sumber Daya Manusia. Jakarta: Gramedia Pustaka Utama

Jahanzeb, Humaira. (2010). The Impact Of Job Stress On Job Satisfaction Among Academic Faculty Of A Mega Distance Learning Institution In Pakistan. Mustang Journal Of Business \& Ethics. Vol:7, Pp: 1-13

Luthan, Fred. (2011). Organizational Behavior, An Evidence-Based Approach. Edisi 12. New York : Megraw-Hill.

Mansoor, M., Jinnah, M. A., Fida, S., Nasir, S. \& Zubair Ahmad. (2011). The Impact of Job Stress on Employee Job Satisfaction A Study on Telecommunication Sector of Pakistan. Journal of Business Studies Quarterly, 2 (3), Pp: 50-56

Parayitam, S.. (2008). From Work-Family Conflicts To Psychological Stress, Job Satisfaction And To Life Satisfaction: A Proposed Integrative Model. Journal Of Organizational Culture, Communications And Conflict,12(2)

Pasewark, W. R. \& Viator, R. E. (2006). Sources Of Work-Family Conflict In The Accounting Profession. Behavioral Research In Accounting, 18, 147-165

Prawitasari, A. K., Purwanto, \& Yuwono, Y. S. (2007). Hubungan Work-Family Conflict Dengan Kepuasan Kerja Pada Karyawati Berperan Jenis Kelamin Androgini Di Pt. Tiga Putera Abadi Perkasa Cabang Purbalingga. Jurnal Ilmiah Berkala Psikologi, 9(2), 1-13 
Prihatini, L. D. (2007). Analisis Hubungan Antara Beban kerja Dengan Stres Kerja Perawat Di Tiap Ruangan Rawat Inap RSUD Sidikalang. USU: Skripsi tidak dipublikasi.

Rahyuda, I K., Murjanayasa, W. dan Yuliarmi, N. N. (2005). Metodologi Penelitian. Denpasar: Ekonomi Udayana.

Rathi, N. \& Barath M. (2013). Work-Family Conflict And Job And Family Satisfaction Moderating Effect Of Social Support Among Police Personnel. Equality, Diversity And Inclusion: An International Journal, 32 (4), 438454

Robbins, S. P. \& Judge, T. A. (2013). Organizational Behavior. Edisi 15, United States of America: Pearson.

Sianturi, M. M. \& Zulkarnain. (2013). Analisis Work Family Conflict Terhadap Kesejahteraan Psikologis Pekerja. Jurnal Sains Dan Praktik Psikologi, 1(3), $207-215$

Soeharto. Triana N. E. D. (2010). Konflik Pekerjaan-Keluarga Dengan Kepuasan Kerja : Metaanalisis. JurnalPsikologi, 37(1), Pp 189 - 194

Sugiyono. (2013). Metode Penelitian Bisnis. Cetakan Ke-17. Bandung: Alfabeta

Susilawati, Endang. (2013). Pengaruh Stres KerjaTerhadap Kepuasan Kerja Dan Kinerja Karyawan Pada Pdam Kabupaten Buton. Thesis Tidak Diterbitkan. Makasar:Jurusan Manajemen, Fakultas Ekonomi Dan Bisnis Universitas Hasanuddin

Sutrisno, E. (2009). Manajemen Sumber Daya Manusia, Jakarta, Kencana Perdana Media Grup.

Tunggareni, H. S. dan Rochmah, T. N. (2013). Job Satisfaction and Performance of Nurse based on Workload in Bhayangkara Hospital Lumajang. Jurnal Administrasi Kesahatan Indonesia, 1(3), pp: 225-233.

Utama, M. S. (2009). Buku Ajar Aplikasi Analisis Kuantitatif. Denpasar: Fakultas Ekonomi Universitas Udayana.

Wibowo, I G. P. (2014). Pengaruh Stres KerjaTerhadap Kepuasan Kerja Dan Komitmen Organisasional Karyawan Ud. Ulam Sari Denpasar. Thesis Tidak Diterbitkan. Denpasar: Program Pascasarjana Universitas Udayana.

Wirawan, Nata. (2002). Statistik 2 (Statistik Inferensia) Untuk Ekonomi dan Bisnis. Denpasar: Keraras Emas.

Yang. N., Chen, C. C., \& Zou, Y. (2000). Source of work-family conflict: A sino U.S. comparison of the effect of work and family demands. Academy of management journal, 43 (1), 113-123.

Zorlu, K. (2012). The Perception Of Self-Esteem And Self-Efficacy As Transforming Factors In The Sources Of Role Stress And Job Satisfaction 
E-Jurnal Manajemen, Vol. 9, No. 3, 2020 : 863-883

Relationship Of Employees: A Trial Of A Staged Model Based On The Artificial Neural Network method. African Journal of Business Management, 6(8), 3014-3025. 